Neurolmages
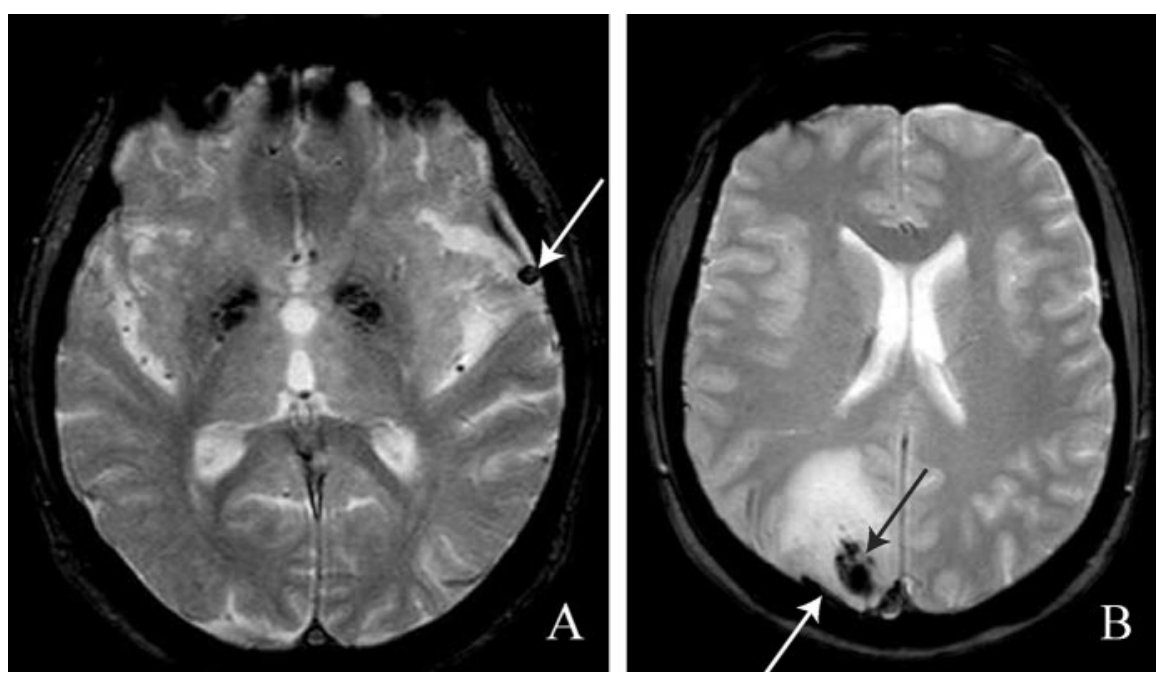

Figure. MRI T2*. (A) Case 1: loss of signal consistent with a thrombosed cortical vein (white arrow). (B) Case 2: right occipital venous hemorrhagic infarction (black arrow), and thrombosed superficial vein (white arrow).

\section{T2*-weighted MRI in cortical venous thrombosis}

S. Cakmak, MD; M. Hermier, MD; A. Montavont, MD; L. Derex, MD; F. Mauguière, MD; P. Trouillas, MD; and N. Nighoghossian, MD, Bron Cedex, France

$\mathrm{T} 2 *$ susceptibility-weighted (T2*SW) MRI enables diagnosis of cerebral venous thrombosis (CVT) by clot visualization as an area

Address correspondence and reprint requests to Prof. N. Nighoghossian, Neurovascular Unit, Hôpital Neurologique et Neurochirurgical P. Wertheimer, 59 Bd Pinel 69677, Bron Cedex, France; e-mail: norbert.nighoghossian@ chu-lyon.fr of hypointensity. ${ }^{1}$ This sequence also contributes to the diagnosis of isolated cortical CVT.

A 78-year-old man suffered a first episode of generalized seizure, right-sided hemiparesis, and confusion (figure, A). A 38year-old woman complained of headache and left hemianopsia (figure, B). MRI was performed on a $1.5 \mathrm{~T}$ scanner 10 days after symptom onset in Case 1 and 3 days in Case 2, including diffusion weighted imaging, conventional $\mathrm{T} 1$ and $\mathrm{T} 2$, proton density, gadolinium enhanced 2D-TOF venography, and T2* SW imaging.

1. Selim M, Fink J, Linfante I, Kumar S, Schlaug G, Caplan LR. Diagnosis of cerebral venous thrombosis with echo-planar T2*-weighted magnetic resonance imaging. Arch Neurol 2002;59:1021-1026. 


\section{Neurology}

\section{T2*-weighted MRI in cortical venous thrombosis}

S. Cakmak, M. Hermier, A. Montavont, et al.

Neurology 2004;63;1698

DOI 10.1212/01.WNL.0000138502.59539.CB

\section{This information is current as of November 8, 2004}

\section{Updated Information \&} Services

References

Citations

Subspecialty Collections

Permissions \& Licensing

Reprints including high resolution figures, can be found at: http://n.neurology.org/content/63/9/1698.full

This article cites 1 articles, 0 of which you can access for free at: http://n.neurology.org/content/63/9/1698.full\#ref-list-1

This article has been cited by 2 HighWire-hosted articles: http://n.neurology.org/content/63/9/1698.full\#\#otherarticles

This article, along with others on similar topics, appears in the following collection(s):

Cerebral venous thrombosis

http://n.neurology.org/cgi/collection/cerebral_venous_thrombosis

MRI

http://n.neurology.org/cgi/collection/mri

Information about reproducing this article in parts (figures,tables) or in its entirety can be found online at:

http://www.neurology.org/about/about_the_journal\#permissions

Information about ordering reprints can be found online:

http://n.neurology.org/subscribers/advertise

Neurology ${ }^{\circledR}$ is the official journal of the American Academy of Neurology. Published continuously since 1951, it is now a weekly with 48 issues per year. Copyright . All rights reserved. Print ISSN: 0028-3878. Online ISSN: 1526-632X.

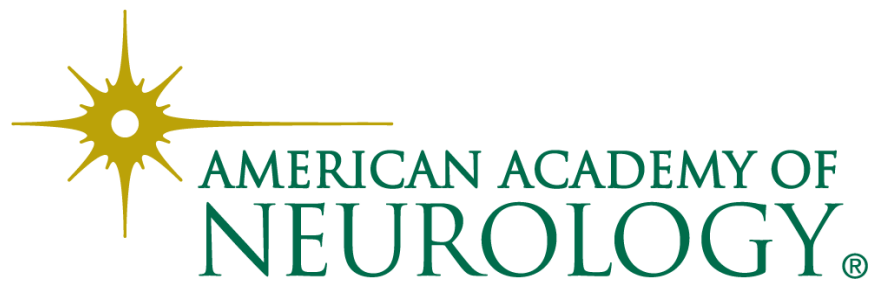

